\title{
PENGARUH CORPORATE SOSIAL RESPONSIBILITY (CSR) TERHADAP KINERJA KEUANGAN PADA PERUSAHAAN MAKANAN DAN MINUMAN YANG TERDAFTAR DI BURSA EFEK INDONESIA
}

\author{
Herna R Simaremare \\ Romasi Lumban Gaol
}

\begin{abstract}
Abstrak
Penelitian ini bertujuan untuk membuktikan secara empiris pengaruh pengungkapan Corporate Social Responsibility terhadap kinerja keuangan perusahaan makanan dan minuman yang terdaftar di bursa efek indonesia (BEI) tahun 20132016.Populasi dalampenelitianiniadalah 18 perusahaan makanan dan minuman. Teknik pengambilan sampel adalah dengan cara purposive sampling sesuai dengan kriteria yang telah ditentukan, sehingga diperoleh 11 perusahaan sampel dengan periode penelitian selama 4 tahun, sehingga jumlah seluruh sampel 44, data diperoleh dari Bursa Efek Indonesia dari tahun 2013 sampai tahun 2016. Teknik analisis data yang digunakan dalam penelitian ini adalah regresi linier sederhana dengan tingkat signifikansi yang dipergunakan adalah 5\% dan untuk pengujian hipotesis digunakan uji t.Hasil uji statistik terbukti bahwaCorporate Social Responsibility (CSR) memiliki pengaruh yang positif dan tidak signifikan terhadap kinerja perusahaan yang diproksikan dengan Return On Asset (ROA) dimana nilai thitung $0,754<$ nilai ttabel 2,017 dan nilai signifikansi $0,455>0,05$. Dan hasil uji statistik terbukti bahwaCorporate Social Responsibility (CSR) memiliki pengaruh yang positif dan signifikan terhadap kinerja perusahaan yang diproksikan dengan Net Profit Margin (NPM) dimana nilai thitung 2,308 > nilai ttabel 2,017 dan nilai signifikansi $0,026<0,05$. Hasil uji koefisien determinasi $\left(\mathrm{r}^{2}\right)$ menunjukkan bahwa besarnya pengaruh Corporate Social Responsibility terhadap kinerja perusahaan yang diproksikan dengan return on assets sebesar 1,3\% dan sisanya 98,7\% dipengaruhi oleh faktor lain. Dan uji koefisien determinasi $\left(\mathrm{r}^{2}\right)$ menunjukkan bahwa besarnya pengaruh Corporate Social Responsibility terhadap kinerja perusahaan yang diproksikan dengan Net Profit Margin sebesar 11,3\% dan sisanya 88,7\% dipengaruhi oleh faktor lain.Saran yang diberikan kepada peneliti selanjutnya hendaknya menambah tahun penelitian, sampel penelitian dan variabel lain yang mempengaruhi kinerja keuangan perusahaan.
\end{abstract}

Kata kunci : Pengungakapan CorporateSocial Responsibility, Kinerja Keuangan Perusahaan

\section{PENDAHULUAN}

Menurut Nugroho (2007), Corporate Social Responsibility(CSR) merupakan klaim stakeholders agar perusahaan tidak hanya beroperasi untuk kepentingan para pemegang saham (shareholders), tapi juga untuk kesejahteraan pihak stakeholders.

Penerapan corporate social responsibility dipercaya dapat meningkatkan kinerja perusahaan, dimana para investor cenderung 
menanamkan modal kepada perusahaan yang melakukan kegiatan CSR. Oleh karena itu, perusahaaan yang memiliki kepedulian sosial dapat menggunakan informasi tanggung jawab sosial (kegiatan CSR ) sebagai salah satu keunggulan kompetitif perusahaan (zuhron dan sukmawati, 2013).

Kinerja perusahaan merupakan suatu ukuran tertentu yang digunakan oleh entitas untuk mengukur keberhasilan dalam menghasilakn laba. Menurut febryani dan zulfadin (2013), kinerja perusahaan merupakan hal yang penting yang harus dicapai oleh setiap perusahaan dimanapun, karena kinerja merupakan cerminan dari kemampuan perusahaan dalam mengelola dan menghasilkan sumber dayanya.

Menurut Kiroyan 2006 dalam Ariweda (2011), Dengan menerapkan CSR, diharapkan perusahaan akan memperoleh legitimasi sosial dan memaksimalkan kekuatan keuangannya dalam jangka panjang. Hal ini mengindikasikan bahwa perusahaan yang menerapkan CSR mengharapkan respon positif oleh para pelaku pasar. Dana yang telah dialokasikan untuk CSR tentunya akan berpengaruh terhadap perusahaan, khususnya terhadap profitabilitas perusahaan.

Profitabilitas merupakan kemampuan suatu perusahaan untuk menghasilkan laba dalam periode tertentu. profitabilitas mengindikasikan seberapa efektif pengelolaan perusahaan secara keseluruhan dan mengukur seberapa besar kemampuan perusahaan memperoleh laba baik dalam hal yang berhubungan dengan penjualan, aset, maupun laba bagi modal sendiri. Dalam penelitian ini peneliti lebih tertarik menggunakkan rasio profitabilitas yaitu Return On Assets (ROA) dan Net Profit Margin (NPM). ROA atau Return on Total Asset, merupakan rasio yang menunjukkan hasil (return) atas jumlah aktiva yang digunakan dalam perusahaan dan NPM atau Net Profit Margin, merupakan rasio yang digunakan untuk mengukur margin laba bersih atas penjualan( Kasmir 2012).

Menurut Lako (2011), salah satu keuntungan apabila perusahaan menerapkan CSR secara berkelanjutan maka profitabilitas dan kinerja perusahaan juga semakin kuat. Pengungkapan CSR dalam laporan tahunan perusahaan digunakan sebagai bahan pertimbangan oleh para investor ketika akan melakukan kegiatan investasi.

Menurut widaryanti (2007), perusahaan yang memiliki tanggung jawab sosial perusahaan yang tinggi akan cenderung memiliki manajemen yang terampil dan berkualitas untuk mengelola perusahaan. Dengan pengelolaan yang baik, maka kinerja perusahaan akan semakin baik. Berdasarkan penjelasan tersebut, maka penelitian ini ditujukan untuk 
menguji secara empiris pengaruh pengungkapan Corporate Social Responsibility (CSR )terhadap Profitabilitas.

\section{TINJAUAN PUSTAKA}

\section{Kinerja Perusahaan}

kinerja adalah hasil kerja yang dapat dicapai oleh seseorang atau kelompok orang dalam suatu perusahaan dengan wewenang dan tanggung jawab masing-masing dalam upaya pencapaian tujuan perusahaan secara legal, tidak melanggar hukum dan tidak bertentangan dengan moral dan etika.

Kinerja perusahaan merupakan suatu ukuran tertentu yang digunakan oleh entitas untuk mengukur keberhasilan dalam menghasilakn laba. Kinerjaperusahaan adalah kemampuan perusahaan untuk menjelaskan kegiatan operasionalnya. Menurut febryani dan zulfadin (2013) kinerja perusahaan merupakan hal yang penting yang harus dicapai oleh setiap perusahaan dimanapun, karena kinerja merupakan cerminan dari kemampuan perusahaan dalam mengelola dan menghasilkan sumber dayanya.

Ada banyak indikator kinerja perusahaan seperti Return On Asset (ROA), Return On Equity (ROE), Net Profit Margin (NPM), Operating Profit Margin (OPM), GrossProfit Margin (GPM), Cash Flow Margin (CFM), Cash Return on Asset, serta Basic Earning Power (BEP). Namun dalam penelitian ini peneliti lebih tertarik menggunakkan rasio profitabilitas yaitu Return On Assets (ROA) dan Net Profit Margin (NPM).

\section{Corporate social Responsibility}

\section{Pengertian Corporate social Responsibility}

Dalam perkembangannya, konsep CSR tidak memiliki defenisi tunggal. Ini terkait pengungkapan dan penjabaran CSR yang dilakukan perusahaan yang juga berbeda-beda. Namun, beberapa yang cukup berpengaruhdiantaranya :

1. Versi uni eropa mengatakan bahwa "pertanggung jawaban sosial perusahaan atau corporate social Responsibility (CSR) adalah mekanisme bagi suatu organisasi untuk secara sukarela mengintegrasikan perhatian terhadap lingkungan dan sosial kedalam operasinya dan interaksinya dengan stakeholders, yang melebihi tanggung jawab organisasi di bidang hukum" 
2. Versi Bank Dunia : "CSR merupakan suatu komitmen berkelanjutan oleh dunia usaha untuk bertindak etis dan memberiakn kontribusi kepada pengembangan ekonomi dari komunitas setempat ataupun masyarakat luas, bersamaan dengan peningkatan taraf hidup pekerjanya beserta seluruh keluarganya.

Belum ada defenisi CSR yang secara universal diterima oleh berbagai lembaga. Beberapa defenisi CSR dibawah ini menunjukkan keragaman pengertian CSR menurut berbagai organisasi, antar lain sebagai berikut:

1. World Business Council for Sustainable Development (WBCSD) CSR adalah komitmen berkesinambungan dari kalangan bisnis untuk berperilaku etis dan memberi kontribusi bagi pembangunan ekonomi, seraya meningkatkan kualitas kehidupan karyawan dan keluarganya, serta komunitas lokal dan masyarakat luas pada umumnya.

2. International Finance Corporation

CSR adalah komitmen dunia bisnis untuk memberi kontribusi terhadap pembangunan ekonomi berkelanjutan melalui kerjasama dengan karyawan, keluarga mereka, komunitas lokal dan masyarakat luas untuk meningkatkan kehidupan mereka melalui cara-cara yang lebih baik bagi bisnis maupun pembangunan.

3. CSR Asia

Komitmen perusahaan untuk beroperasi secara berkelanjutan berdasarkan prinsip ekonomi, sosial dan lingkungan, seraya menyeimbangkan beragam kepentingan para stakeholders.

Item pengungkapan dalam penelitian ini kemudian dinyatakan dalam bentuk indeks pengungkapan sosial (www.gri.com) atau Global Reporting initiativeyang terdiri dari:

1) Lingkungan

1. Pengendalian polusi kegiatan operasi, pengeluaran riset dan pengembangan untuk mengurangi polusi.

2. Operasi perusahaan tidak mengakibatkan polusi atau memenuhi ketentuan hukum dan peraturan polusi.

3. Pernyataan yang menunjukkan bahwa polusi operasi telah dikurangi atau akan dikurangi.

4. Pencegahan tau perbaikan kerusakan lingkungan akibat pengelolaan sumber alam, misalnya reklamasi daratan atau reboisasi.

5. Konservasi sumber alam, misalnya mendaur ulang kaca, besi, minyak, air dan kertas. 
6. Penggunaan material daur ulang.

7. Menerima penghargaan berkaitan dengan program lingkungan yang dibuat perusahaan.

8. Merancang fasilitas yang harmonis dengan lingkungan.

9. Kontribusi dalam seni yang bertujuan untuk memperindah lingkungan.

10. Kontribusi dalam pemugaran bangunan sejarah.

11. Pengelolaan limbah.

12. Riset mengenai pengelolaan limbah.

13. Mempelajari dampak lingkungan untuk memonitor dampak lingkungan perusahaan.

14. Perlindungan lingkungan hidup.

2) Energi

1. Menggunakan energi secara lebih efisien dalam kegiatan operasi.

2. Memanfaatkan barang bekas untuk memproduksi energi.

3. Penghematan energi sebagai hasil produk daur ulang.

4. Membahas upaya perusahaan dalam mengurangi konsumsi energi.

5. Peningkatan efisiensi energi dan produk.

6. Riset yang mengarah pada peningkatan efisiensi energi dari produk.

7. Mengungkapkan kebijakan energi perusahaan.

\section{3) Kesehatan dan Keselamatan Kerja}

1. Mengurangi polusi, iritasi, atau resiko dalam lingkungan kerja.

2. Mempromosikan keselamatan tenaga kerja dan kesehatan fisik atau mental.

3. Mengungkapkan statistik kecelakaan kerja.

4. Mentaati peraturan standar kesehatan dengan keselamatan kerja.

5. Menerima penghargaan berkaitan dengan keseslamatan kerja.

6. Menetapkan suatu komite keselamatan kerja.

7. Melaksanakan riset untuk meningkatkan keselamatan kerja.

8. Mengungkapakan pelayanan kesehatan tenaga kerja.

\section{4) Lain-lain Tentang Tenaga Kerja}

1. Perekrutan atau memanfaatkan tenaga kerja wanita / orang cacat.

2. Mengungkapkan persentase/ jumlah tenaga kerja wanita / orang cacat dalam tingkat manajerial.

3. Mengungkapkan tujuan penggunaan tenaga kerja wanita / orang cacat dalam pekerjaan.

4. Program untuk kemajuan tenaga kerja wanita / orang cacat.

5. Pelatihan tenaga kerja melalui program tertentu di tempat kerja. 
6. Memberikan bantuan keuangan pada tenaga kerja dalam bidang pendidikan.

7. Mendirikan suatu pusat pelatihan tenaga kerja.

8. Mengungkapkan bantuan atau bimbingan untuk tenaga kerja yang dalam proses mengundurkan diri atau yang telah membuat kesalahan,

9. Mengungkapkan perencanaan kepemilikan rumah karyawan.

10. Mengungkapkan fasilitas untuk aktivitas rekreasi.

11. Pengungkapan persentase gaji untuk pensiun.

12. Mengungkapkan kebijakan penggajian dalam perusahaan.

13. Mengungkapkan jumlah tenaga kerja dalam perusahaan.

14. Mengungkapkan tingkatan manajerial yang ada.

15. Mengungkapkan disposisi staff dimana staff ditempatkan.

16. Mengungkapkan jumlah staff, masa kerja dan kelompok usia mereka.

17. Mengungkapkan statistik tenaga kerja, misalnya penjualan per tenaga kerja.

18. Mengungkapkan kualifikasi tenaga kerja yang direkrut.

19. Mengungkapkan rencana kepemilikan saham oleh tenaga kerja.

20. Mengungkapkan rencana pembagian keuntungan lain.

21. Mengungkapkan informasi hubungan manajemen dengan tenaga kerja dalam meningkatkan keputusan dan motivasi kerja.

22. Mengungkapkan informasi stabilitas pekerjaan tenaga kerja dan masa depan perusahaan.

23. Membuat laporan tenaga kerja yang terpisah.

24. Melaporkan hubungan perusahaan dengan dengan serikat buruh.

25. Melaporkan gangguan dan aksi tenaga kerja.

26. Mengungkapkan informasi bagaimana aksi tenaga kerja dinegosiasikan.

27. Peningkatan kondisi kerja secara umum.

28. Informasi reorganisasi perusahaan yang mempengaruhi tenaga kerja .

29. Informasi dan statistik perputaran tenaga kerja.

\section{5) Produk}

1. pengungkapan informasi pengembangan produk perusahaan, termasuk pengemasan.

2. Gambaran pengeluaran riset dan pengembangan produk.

3. Pengungkapan informasi proyek riset perusahaan untuk memperbaiki produk.

4. Pengungkapan bahwa produk memenuhi standar keselamatan.

5. Membuat produk lebih aman untuk konsumen.

6. Melaksanakan riset atas tingkat keselamatan produk perusahaan.

7. Pengungkapan peningkatan kebersihan/kesehatan dalam pengolahan dan penyiapan produk 
8. Pengungkapan informasi atas keselamatan produk perusahaan.

9. Pengungkapan informasi mutu produkyang dicerminkan dalam penerimaan penghargaan.

10. Informasi yang dapat diverifikasi bahwa mutu produk telah meningkat (misalnya, ISO 9000)

\section{6) Keterlibatan masyarakat}

1. Sumbangan tunai, produk, pelayanan untuk mendukung aktivitas masyarakat, pendidikan, dan seni.

2. Tenaga kerja paruh waktu (part-time employment) dari mahasiswa atau pelajar.

3. Sebagai sponsor untuk proyek kesehatan masyarakat.

4. Membantu riset media.

5. Sebagai sponsor untuk konferensi pendidikan, seminar atau pameran seni.

6. Membiayai program beasiswa.

7. Membuka fasilitas perusahaan untuk masyarakat.

8. Mensponsori kampanye nasional.

9. Mendukung perkembangan industri lokal.

\section{7) Umum}

1. Pengungkapan tujuan, kebijakan perusahaan secara umum berkaitan dengan tanggung jawab sosial perusahaan kepada masyarakat.

2. Informasi hubungan dengan tanggung jawab sosial perusahaan selain yang disebut diatas.

\section{Kerangka Berpikir}

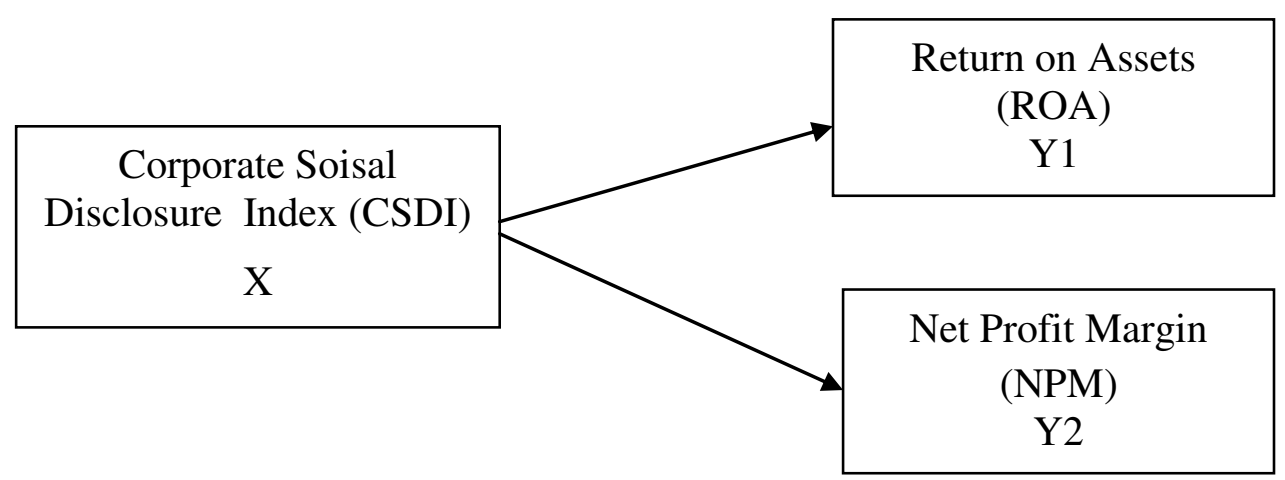




\section{Pengaruh Pengungkapan Corporate Social Responsibility Terhadap Return On Assets}

Untuk mengukur seberapa efektif perusahaan beroperasi sehingga menghasilkan keuntungan atau mencapai profit keseluruhan terutama dalam hubungannya dengan sumber-sumber yang diinvestasikan dalam aset-aset perusahaan digunakan rasio return on assets (R0A).ROA mengukur seberapa besar efektivitas perusahaan dalam menggunakan asetnya. Semakin tinggi ROA, maka semakin efektif penggunaan aset perusahaan tersebut Artinya, semakin baik produktifitas aset dalam memperoleh keuntungan bersih maka akan meningkatkan daya tarik investor kepada perusahaan karena tingkat pengembalian atau deviden akan semakin besar. Hal tersebut juga akan berdampak baik pada harga saham dari perusahaan. ROA membantu perusahaan menjalankan praktik akuntansi dengan baik karena untuk mengukur efisiensi penggunaan modal yang menyeluruh, sehingga dapat diketahui resiko dan posisi keuangan perusahaan.

\section{Pengaruh Pengungkapan Corporate Social Responsibility Terhadap Net Profit Margin}

Tanggung jawab social perusahaan merupakan suatu bentuk pertanggungjawaban yang dilakukan oleh suatu perusahaan dalam memperbaiki kesenjangan sosial dan kerusakan-kerusakan lingkungan yang terjadi akibat dari ativitas operasional yang dilakukan perusahaan. Semakin banyak bentuk pertanggungjawaban yang dilakukan oleh suatu perusahaan terhadap lingkungannya, maka semakin baik citra perusahaan .

Investor lebih berminat pada perushaan yang memiliki citra yang baik dimasyarakat karena semakin baiknya citra perusahaan maka semakin tinggi juga loyalitas konsumen .seiring meningkatnya loyalitas konsumen dalam waktu lama maka penjualan perusahaan akan meningkat diharapkan tingkat profitabilitas perusahaan juga meningkat. Secara teoritis, suatu perusahaan dikatakan mempunyai nilai dan reputasi yang baik jika kinerja keuangan perusahaan juga baik .

\section{Hipotesis}

Perusahaan yang melakukan CSR memiliki keunggulan di mata stakeholder dibanding dengan perusahaan yang tidak melakukan aktivitas CSR. Menurut Finch (2005), mengatakan bahwa motivasi perusahaan 
menggunakan sustainability reporting framework adalah untuk mengkomunikasikan kinerja manajemen dalam mencapai keutungan jangka panjang perusahaan kepada para stakeholder, seperti perbaikan kinerja perusahaan,memaksimumkan profit, serta kesuksesan perusahaan dalam jangka panjang.

Berdasarkan uraian diatas maka hipotesis yang dapat dirumuskan adalah:

H1: Pengungkapan CSR berpengaruh terhadap kinerja perusahaan yang diukur dengan Return On Asset.

H2: Pengungkapan CSR berpengaruh terhadap kinerja perusahaan yang diukur dengan Net Profit Margin.

\section{METODE PENELITIAN}

\section{Populasi dan Ampel}

Populasi dalam penelitian ini sebanyak 18perusahaan makanan dan minuman yang terdaftar di bursa terdaftar di Bursa Efek Idonesia periode 2013-2016.Sampel penelitian yang digunakan 11 perusahaan. Jumlah pengamatan selama 4 tahun. Maka jumlah sampel adalah $11 \times 4=44$

\section{Operasionalisasi variabel}

a. Return on assets (ROA)

Menurut Kasmir (20014:201) ROA adalah suatu rasio profitabilitas yang menunjukan hasil (return) atas jumblah aktiva yang digunakan dalam perusahaan.

\section{b. Net Propit Margin (NPM)}

Menurut Kasmir (2012:199) NPM adalah rasio profitabilitas yang digunakan untuk mengukur keuntungan dengan membandingkan laba bersih dengan penjualan.

\section{c. Corporate SocialResposibility}

Adalah mekanisme bagi suatu perusahaan untuk secara sukarela mengintegrasikan perhatian terhadap lingkungan sosial ke dalam operasinya dan interaksinya dengan stakeholder, yang melebihi tanggung jawab sosial dibidang hukum (Darwin 2004). Dalam penelitian ini variabeldependen yaitu CSR akan diukur dengan menggunakan Corporate Social Disclosure Index (CSDI). 
Tabel 1. Operasionalisasi Variabel

\begin{tabular}{|c|c|c|c|c|}
\hline No & Variabel & Indikator & Pengukuran & Skala \\
\hline 1 & $\begin{array}{l}\text { Variabel } \\
\text { independen : } \\
\text { corporate } \\
\text { social } \\
\text { Responsibilit } \\
\text { y (CSR) }\end{array}$ & $\begin{array}{l}\text { Corporate } \\
\text { Social } \\
\text { Disclousure } \\
\text { Index } \\
\text { (CSDI) }\end{array}$ & $\mathrm{CSDIj}=\frac{\sum x i j}{N i j}$ & Rasio \\
\hline 2 & $\begin{array}{l}\text { Variabel } \\
\text { dependen : } \\
\text { Kinerja } \\
\text { perusahaan } \\
\text { yang diukur } \\
\text { dengan } \\
\text { Rasio } \\
\text { Profitabilitas }\end{array}$ & $\begin{array}{l}\text { Return On } \\
\text { Asset (ROA) } \\
\text { Net Profit } \\
\text { Margin } \\
\text { (NPM) }\end{array}$ & $\begin{array}{l}R O A=\frac{\text { LabaBersi } \square}{\text { Totalaktiva }} \times 100 \% \\
N P M=\frac{\text { LabaSetela } \square \text { bungadanPajak }}{\text { Penjualan }} \times 100 \%\end{array}$ & $\begin{array}{l}\text { Rasio } \\
\text { Rasio }\end{array}$ \\
\hline
\end{tabular}

\section{Teknik Analisis Data}

Teknik analisis yang digunakan dalam penelitian ini adalah analisis regresi linier sederhana. Teknik analisis linier sederhana berguna untuk menguji pengaruh satu variabel independen terhadap satu variabel dependen. Untuk mengetahui besarnya pengaruh variabel independen terhadap variabel dependen digunakan model sebagai berikut :

$$
\begin{aligned}
& \mathrm{Y} 1=\alpha+\beta \mathrm{X}+\varepsilon \\
& \mathrm{Y} 2=\alpha+\beta \mathrm{X}+\varepsilon
\end{aligned}
$$

Keterangan :

$\begin{array}{ll}\text { Y1 } & : \text { Return On Asset } \\ \text { Y2 } & : \text { Net Profit Margin } \\ \mathrm{X} & : \text { : Corporate Social Responsibility Disclosure Index } \\ \alpha & : \text { Konstanta } \\ \beta & : \text { koefisien Regresi } \\ \varepsilon & : \text { Distrubance Error (faktor pengganggu/residual) }\end{array}$




\section{HASIL PENELITIAN DAN PEMBAHASAN}

\section{Hasil Uji Asumsi Klasik}

Tabel 2. One-Sample Kolmogorov-Smirnov Test

\begin{tabular}{|ll|r|r|r|}
\hline & & \multicolumn{1}{c|}{ ROA } & \multicolumn{1}{c|}{ NPM } & \multicolumn{1}{c|}{ CSR } \\
\hline $\mathrm{N}$ & & 44 & 44 & 44 \\
Normal Parameters ${ }^{\mathrm{a}, \mathrm{b}}$ & Mean & 6.9847 & 6.7724 & 7.4313 \\
& Std. Deviation & .74850 & .72047 & .53470 \\
& Absolute & .065 & .117 & .084 \\
Most Extreme Differences & Positive & .062 & .086 & .084 \\
& Negative & -.065 & -.117 & -.082 \\
Kolmogorov-Smirnov Z & & .431 & .776 & .559 \\
Asymp. Sig. (2-tailed) & & .992 & .584 & .914 \\
\hline
\end{tabular}

a. Test distribution is Normal.

b. Calculated from data.

Sumber : Hasil Output SPSS 21 (data diolah)

Dengan melihat hasil uji normalitas pada tabel diatas, nilai asymp. Sig. (2-tailed) untuk variabel CSR adalah 0,914 dimana 0,914>0,05, sehingga dapat dinyatakan bahwa data berdistribusi normal. Untuk variabel ROA adalah 0,992 dimana 0,992>0,05, sehingga dapat dinyatakan bahwa data berdistribusi normal. Serta untuk variabel NPM adalah 0,584 dimana 0,584>0,05, sehingga dapat dinyatakan bahwa data berdistribusi normal.

Tabel 3. Hasil Uji Autokorelasi ROA
Model Summary
\begin{tabular}{|l|c|r|c|c|c|}
\hline $\begin{array}{l}\text { Mode } \\
1\end{array}$ & R & R Square & $\begin{array}{c}\text { Adjusted R } \\
\text { Square }\end{array}$ & $\begin{array}{l}\text { Std. Error of } \\
\text { the Estimate }\end{array}$ & $\begin{array}{l}\text { Durbin- } \\
\text { Watson }\end{array}$ \\
\hline 1 & $.116^{\mathrm{a}}$ & .013 & -.010 & .75229 & 2.445 \\
\hline
\end{tabular}

a. Predictors: (Constant), CSR

b. Dependent Variable: ROA

Sumber : Hasil Output SPSS 21 (data diolah)

Berdasarkan tabel diatas, nilai DW untuk variabel dependen ROA adalah 2,380. nilai ini dibandingkan dengan nilai DW tabel DW. Dengan jumlah sampel penelitian (n) 44 dan jumlah variabel independen $(\mathrm{K}=1)$ maka diperoleh nilai $\mathrm{du}=1,4692 \mathrm{dan} \mathrm{dl}=1,5619$ pada tabel DW. Dengan 
demikian untuk variabel dependen ROA nilai du $<\mathrm{dw}<4$-du $(1,4692<2,445<2,5308)$, sehinga dapat disimpulkan bahwa tidak terdapat autokorelasi baik positif maupun negatif. dengan demikian model regresi linier sederhana layak pada penelitian ini karena data pada penelitian ini bebas dari masalah auto korelasi.

\section{Model Summary ${ }^{\mathrm{b}}$}

Tabel 4. Hasil Uji Autokorelasi NPM

\begin{tabular}{|l|r|r|r|r|r|}
\hline $\begin{array}{l}\text { Mode } \\
1\end{array}$ & R & R Square & $\begin{array}{c}\text { Adjusted R } \\
\text { Square }\end{array}$ & $\begin{array}{c}\text { Std. Error of } \\
\text { the Estimate }\end{array}$ & $\begin{array}{c}\text { Durbin- } \\
\text { Watson }\end{array}$ \\
\hline 1 & $.336^{\mathrm{a}}$ & .113 & .091 & .68673 & 2.128 \\
\hline
\end{tabular}

a. Predictors: (Constant), CSR

b. Dependent Variable: NPM

Sumber : Hasil Output SPSS 21 (data diolah)

Berdasarkan tabel diatas, nilai DW untuk variabel dependen NPM adalah 1,849. nilai ini dibandingkan dengan nilai DW tabel DW. Dengan jumlah sampel penelitian (n) 44 dan jumlah variabel independen $(K=1)$ maka diperoleh nilai du $=1,4692$ dan $\mathrm{dl}=1,5619$ pada tabel DW. Dengan demikian untuk variabel dependen NPM nilai du $<\mathrm{dw}<4$-du $(1,4692<2,128<2,5308)$, sehinga dapat disimpulkan bahwa tidak terdapat autokorelasi baik positif maupun negatif. dengan demikian model regresi linier sederhana layak pada penelitian ini karena data pada penelitian ini bebas dari masalah auto korelasi.

\section{Uji Hipotesis}

Coefficients

Tabel 5. Persamaan Regresi Linier Sederhana ROA

\begin{tabular}{|rl|r|r|r|r|r|}
\hline \multirow{2}{*}{ Model } & \multicolumn{2}{|c|}{$\begin{array}{c}\text { Unstandardized } \\
\text { Coefficients }\end{array}$} & \multicolumn{1}{c|}{$\begin{array}{c}\text { Standardized } \\
\text { Coefficients }\end{array}$} & \multirow{2}{*}{ Sig. } & \\
\cline { 3 - 5 } & \multicolumn{1}{|c|}{ B } & \multicolumn{1}{c|}{ Std. Error } & \multicolumn{1}{c|}{ Beta } & & \\
\hline \multirow{2}{*}{1} & (Constant) & -1.938 & .398 & & -4.867 & .000 \\
& CSR & .162 & .215 & .116 & .754 & .455 \\
\hline
\end{tabular}

a. Dependent Variable: ROA

Sumber : Hasil Output SPSS 21 (data diolah)

Dari tabel diatas, dapat dirumuskan persamaan regresi

liniersederhana sebagai berikut :

Return On Asset = -1,938+0,162CSRI+e 
Persamaan regresi linier sederhana diatas memiliki makna sebagai berikut :

1. Konstanta untuk nilai variabel Y (ROA) adalah -1,938, Hal ini menunjukkan bahwa apabila variabel X (CSR) adalah 0, maka tingkat ROA yang diperoleh perusahaan akan menurun sebesar 1,938.

2. Koefisien regresi untuk variabel X (CSR) adalah sebesar 0,162. Berarti nilai koefisien tersebut menunjukkan bahwa CSR berpengaruh positif terhadap tingkat ROA. Hal ini menggambarkan ketika CSR naik 1\% maka ROA akan naik sebesar 16,2\% dan sebaliknya.

\section{Coefficients $^{\mathrm{a}}$}

Tabel 6. Persamaan Regresi Linier Sederhana NPM

\begin{tabular}{|rl|r|r|r|r|r|}
\hline \multirow{2}{*}{ Model } & \multicolumn{2}{|c|}{$\begin{array}{c}\text { Unstandardized } \\
\text { Coefficients }\end{array}$} & $\begin{array}{c}\text { Standardized } \\
\text { Coefficients }\end{array}$ & \multirow{2}{*}{ T } & \multirow{2}{*}{ Sig. } \\
\cline { 2 - 5 } & \multicolumn{1}{|c|}{ B } & Std. Error & \multicolumn{1}{c|}{ Beta } & & \\
\hline \multirow{2}{*}{1} & (Constant) & -1.634 & .363 & & -4.494 & .000 \\
& CSR & .452 & .196 & .336 & 2.308 & .026 \\
\hline
\end{tabular}

a. Dependent Variable: NPM

Sumber : Hasil Output SPSS 21 (data diolah)

Dari tabel diatas, dapat dirumuskan persamaan regresi

liniersederhana sebagai berikut :

Return On Asset = -1,634+0,452CSRI+e

Persamaan regresi linier sederhana diatas memiliki makna sebagai berikut :

1. Konstanta untuk nilai variabel Y (ROA) adalah -1,634, Hal ini menunjukkan bahwa apabila variabel X (CSR) adalah 0, maka tingkat NPM yang diperoleh perusahaan akan menurun sebesar 1,634.

2. Koefisien regresi untuk variabel X (CSR) adalah sebesar 0,452. Berarti nilai koefisien tersebut menunjukkan bahwa CSR berpengaruh positif terhadap tingkat NPM. Hal ini menggambarkan ketika CSR naik $1 \%$ maka NPM akan naik sebesar 45,2\% dan sebaliknya.

\section{Koefisien Determinasi}

Tabel 7. Hasil Koefisien Determinasi ROA

Model Summary ${ }^{b}$

\begin{tabular}{|l|r|r|r|r|r|}
\hline $\begin{array}{l}\text { Mode } \\
1\end{array}$ & $\mathrm{R}$ & $\mathrm{R}$ Square & $\begin{array}{c}\text { Adjusted R } \\
\text { Square }\end{array}$ & $\begin{array}{c}\text { Std. Error of } \\
\text { the Estimate }\end{array}$ & $\begin{array}{c}\text { Durbin- } \\
\text { Watson }\end{array}$ \\
\hline 1 & $.116^{\mathrm{a}}$ & .013 & -.010 & .75229 & 2.445 \\
\hline
\end{tabular}

a. Predictors: (Constant), CSR

b. Dependent Variable: ROA

Sumber : Hasil Output SPSS 21 (data diolah) 
Berdasarkan tabel diatas, nilai koefisien determinasi $\left(\mathrm{r}^{2}\right)$ untuk pengaruh variabelCSR terhadap ROA adalah sebesar 0,013 atau hanya $1,3 \%$. Angka tersebut menunjukkan bahwa variabel independen (corporate social responsibility) secara bersama sama mempengaruhi variabel dependen (kinerja keuangan) sebesar 1,3\%. dan sisanya 98,7\% dipengaruhi oleh variabel seperti perputaran modal kerja, aspek pendapatan, rasio likuiditas, ukuran perusahaan dan berbagai faktor lain yang mampu mempengaruhi ROA.

Model Summary ${ }^{\mathrm{b}}$

\section{Tabel 8. Hasil Koefisien Determinasi NPM}

\begin{tabular}{|l|r|r|r|r|r|}
\hline $\begin{array}{l}\text { Mode } \\
1\end{array}$ & \multicolumn{1}{|c|}{$\mathrm{R}$} & R Square & $\begin{array}{c}\text { Adjusted R } \\
\text { Square }\end{array}$ & $\begin{array}{c}\text { Std. Error of } \\
\text { the Estimate }\end{array}$ & $\begin{array}{c}\text { Durbin- } \\
\text { Watson }\end{array}$ \\
\hline 1 & $.336^{\mathrm{a}}$ & .113 & .091 & .68673 & 2.128 \\
\hline
\end{tabular}

a. Predictors: (Constant), CSR

b. Dependent Variable: NPM

Sumber : Hasil Output SPSS 21 (data diolah)

Berdasarkan tabel diatas, nilai koefisien determinasi $\left(\mathrm{r}^{2}\right)$ untuk pengaruh variabelCSR terhadap NPM adalah sebesar 0,113 atau hanya 11,3\%. Angka tersebut menunjukkan bahwa variabel independen (corporate social responsibility) secara bersama sama mempengaruhi variabel dependen (kinerja keuangan) sebesar 11,3\%. dan sisanya 88,7\% dipengaruhi oleh variabel seperti perputaran modal kerja, aspek pendapatan, rasio likuiditas, ukuran perusahaan dan berbagai faktor lain yang mampu mempengaruhi NPM.

Coefficients $^{\mathrm{a}}$

Tabel 9. Uji statistik t ROA

\begin{tabular}{|rl|r|r|r|r|r|}
\hline \multicolumn{2}{|l|}{ Model } & \multicolumn{2}{|c|}{$\begin{array}{c}\text { Unstandardized } \\
\text { Coefficients }\end{array}$} & $\begin{array}{c}\text { Standardized } \\
\text { Coefficients }\end{array}$ & \multirow{2}{*}{$\mathrm{t}$} & \multirow{2}{*}{ Sig. } \\
\cline { 2 - 5 } & \multicolumn{1}{|c|}{$\mathrm{B}$} & Std. Error & \multicolumn{1}{c|}{ Beta } & & \\
\hline \multirow{2}{*}{1} & (Constant) & -1.938 & .398 & & -4.867 & .000 \\
& CSR & .162 & .215 & .116 & .754 & .455 \\
\hline
\end{tabular}

a. Dependent Variable: ROA

Sumber : Hasil Output SPSS 21 (data diolah)

Dari tabel diatas nilai koefisien menunjukkan bahwa $\mathrm{t}$ hitung variabel pengungkapan corporate social responsibility 0,754 dengan Signifikansi 0,455 . Nilai t-hitung $0,754<$ nilai t-tabel 2,017 sedangkan tingkat signifikansi 0,455 lebih besar dari tingkat keyakinan $5 \%$ 
$(0,455>0,05)$. Hal ini berarti Corporate Social Responsibility (CSR) berpengaruh positif dan tidak signifikan terhadap kinerja perusahaan yang diukur dengan Return On Asset pada perusahaan makanan dan minuman yang terdaftar di bursa efek indonesia periode 2013-2016, maka dapat disimpulkan bahwa pengungkapan CSR berpengaruh positif dan tidak signifikan terhadap Return On Asset, sehingga Ho ditolak.

Coefficients $^{\mathbf{a}}$

\section{Tabel 10. Uji statistik t NPM}

\begin{tabular}{|c|c|c|c|c|c|}
\hline \multirow[t]{2}{*}{ Model } & \multicolumn{2}{|c|}{$\begin{array}{l}\text { Unstandardized } \\
\text { Coefficients }\end{array}$} & $\begin{array}{l}\text { Standardized } \\
\text { Coefficients }\end{array}$ & \multirow[t]{2}{*}{$\mathrm{t}$} & \multirow[t]{2}{*}{ Sig. } \\
\hline & $\mathrm{B}$ & Std. Error & Beta & & \\
\hline (Constant) & -1.634 & .363 & & -4.494 & .000 \\
\hline CSR & .452 & .196 & .336 & 2.308 & .026 \\
\hline
\end{tabular}

a. Dependent Variable: NPM

Sumber : Hasil Output SPSS 21 (data diolah)

Dari tabel diatas nilai koefisien menunjukkan $\mathrm{t}$ hitung variabel pengungkapan Corporate sicial Responsibility (CSR) sebesar 2,308 dengan signifikansi 0,026. Nilai t-hitung 2,308 >t-tabel 2,017 sedangkan tingkat signifikansi 0,026 lebih besar dari tingkat keyakinan 5\% $(0,026<0,05)$. Hal ini berarti Corporate Social Responsibility (CSR) berpengaruh positif dan signifikan terhadap kinerja perusahaan yang diukur dengan Net Profit Margin pada perusahaan makanan dan minuman yang terdaftar di bursa efek indonesia periode 2013-2016, sehingga hipotesis yang menyatakan pengungkapan Corporate sosial responsibility berpengaruh signifikan terhadap kinerja perusahaan yang diukur dengan Net Profit Margin diterima.

\section{PEMBAHASAN}

\section{Pengaruh Pengungkapan CSR terhadap Kinerja perusahaan yang diukur dengan Return On Asset}

Koefisien regresi variabel pengungkapan Corporate social Responsibility (CSR) bernilai positif sebesar 0,162. nilai t-hitung sebesar 0,754 dengan signifikansi 0,455 . Nilai t-hitung $0,754<$ nilai t-tabel 2,017 sedangkan tingkat signifikansi 0,455 lebih besar dari tingkat keyakinan 5\% $(0,455>0,05)$. Hal ini berarti Corporate Social Responsibility (CSR) berpengaruh positif dan tidak signifikan terhadap kinerja perusahaan yang diukur dengan Return On Asset pada perusahaan makanan dan minuman 
yang terdaftar di bursa efek indonesia periode 2013-2016, sehingga hipotesis yang menyatakan pengungkapan Corporate sosial responsibility berpengaruh signifikan terhadap kinerja keuangan yang diukur dengan Return On Asset ditolak.Hal ini dapat diintrepretasikan bahwa semakin tinggi indeks pengungkapan CSR yang dilakukan perusahaan, tidak berpengaruh signifikan terhadap return on asset (ROA) yang diperoleh perusahaan.

Hasil penelitian ini tidak mendukung penelitian yang dilakukan Lintang Kurniawati (2012) yaitu tanggung jawab sosial memiliki pengaruh yang signifikan terhadap profitabilitas yang diukur dengan ROA.Akan tetapi, penelitian ini mendukung hasil penelitian Fauzi et al (2007) yaitu corporate social performance tidak menunjukkan hubungan yang signifikan terhadap ROA.Hal ini didukung dengan argumen bahwa dengan adanya kegiatan CSR menjadi biaya bagi perusahaan yang dapat mengurangi atau tidak dapat meningkatkan laba bersih perusahaan tersebut secara signifikan. Peningkatan aset apabila tidak diimbangi dengan peningkatan laba akan berakibat pada rasio return on asset (ROA) yang rendah.

\section{Pengungkapan Pengungkapan CSR terhadap Kinerja perusahaan yang diukur dengan Net Profit Margin}

Koefisien regresi variabel pengungkapan Corporate sicial Responsibility (CSR) bernilai positif sebesar 0,452. nilai t-hitung sebesar 2,308 dengan signifikansi 0,026. Nilai t-hitung 2,308 >t-tabel 2,017 sedangkan tingkat signifikansi 0,026 lebih besar dari tingkat keyakinan 5\% $(0,026<0,05)$. Hal ini berarti Corporate Social Responsibility (CSR) berpengaruh positif dan signifikan terhadap kinerja perusahaan yang diukur dengan Net Profit Margin pada perusahaan makanan dan minuman yang terdaftar di bursa efek indonesia periode 2013-2016, sehingga hipotesis yang menyatakan pengungkapan Corporate sosial responsibility berpengaruh signifikan terhadap kinerja perusahaan yang diukur dengan Net Profit Margin diterima.Hal ini dapat diintrepretasikan bahwa semakin tinggi indeks pengungkapan CSR yang dilakukan perusahaan, berpengaruh secara signifikan pada peningkatan net profit margin (NPM) yang diperoleh perusahaan. 
Hasil penelitian ini mendukung penelitian Almar (2012) yang menunjukkan bahwa pengungkapan CSR perusahaan berpengaruh signifikan terhadap Net Profit Margin, dimana semakin tinggi pengungkapan corporate social responsibility tentu akan mendapatkan respect lebih rendah, daripada perusahaan yang tidak melakukan pengungkapan corporate social responsibility. dengan pengungkapan CSR perusahaan mampu menarik perhatian konsumen sehingga tingkat penjualan dapat meningkat dengan meningkatnya margin laba perusahaan. semakin baik pengungkapan CSR perusahaan, khususnya pengungkapan yang beriorientasi pada produk dan konsumen maka margin laba dapat meningkat. namun, Hasil penelitian ini tidak mendukung penelitian yang dilakukan Ariwenda (2011) yang menyatakan bahwa pengungkapan CSR tidak berpengaruh terhadap NPM. hal ini disebabkan karena objek penelitian yang berbeda sehingga hasil penelitian juga berbeda.

\section{DAFTAR PUSTAKA}

Ajilaksana. 2013. Pengaruh Corporate Social Responsibility Terhadap Kinerja Perusahaan. Skripsi. Semarang: Fakultas Ekonomi Universitas Diponegoro.

Alit. 2013. Pengaruh pengungkapan CSR terhadap kinerja keuangan perusahaan pertambangan yang terdaftar di Bursa Efek Indonesia. Jurnal Akuntansi Universitas Udayana.

Anggara. 2015.pengaruh pengungkapan CSR terhadap kinerja keuangan perusahaan yang terdaftar di Bursa Efek Indonesia. simposium nasional akuntansi 6, Yogyakarta.

Bursa Efek Indonesia. Laporan Tahunan Bursa Efek Indonesia. (www.idx.co.id), (diakses pada 06 Februari 2018).

Daniri, Achmad. 2008. Standarisasi Tanggungjawab Sosial Perusahaan. (http://www.madani-ri.com). Diakses 15 Februari 2018.

Ghozali, H Imam. 2006. Aplikasi Analisis Multivariate Dengan Program SPSS. Semarang : Badan Penerbit Universitas Diponegoro. 
Ibnu. 2012. Pengaruhcorporate social responsibilityterhadap kinerja keuangan perusahaan manufaktur yang terdaftar di Bursa Efek Indonesia. Jurnal Akuntansi Universitas Dian Nusantara.

Indrawan, Danu Candra. 2011. Pengaruh Corporate Social Responsibility Terhadap Kinerja Perusahaan. Skripsi. Semarang: Fakultas EkonomiUniversitas Diponegoro.

Kadek, rosiliana. 2014. pengaruh pengungkapan CSR terhadap kinerja keuangan perusahaan yang terdaftar di Bursa Efek Indonesia. Jurnal Akuntansi Universitas Pendidikan Ganesha Bamdung .

Kamaludin. 2010. Pengaruh Corporate Social Responsibility Terhadap Kinerja Perusahaan. Skripsi. Semarang: Fakultas Ekonomi Universitas Islam Negeri Jakarta.

Kartini, Dwi. 2009. corporate sosial responsibilitytransformasi konsep sustainability managementdan implementasi di indonesia. Bandung: PT Refika Aditama.

Kasmir. 2012. Analisis Laporan Keuangan. Jakarta: PT Raja Grafindo Persada.

Lako, Andreas. 2011.Dekonstruksi CSR \& Reformasi Paradigma Bisnis dan Akuntansi. Jakarta: Erlangga.

Satria, Emerald. 2013. Pengaruh Corporate Social Responsibility Terhadap Kinerja Perusahaan. Skripsi. Semarang: Fakultas Ekonomi Universitas Diponegoro.

Sembiring, E.R. 2005. Karakteristik perusahaan dan pengungkapan tanggungjawab sosial: study empiris pada perusahaan yang tercatat di Bursa Efek Jakarta, Simposium Nasional Akuntansi VIII.

Sugyono. 2015. Statistika Untuk Penelitian. Bandung: Alfabeta.

Undang-undang No. 40 tahun 2007 tertang Perseroan Terbatas. 